\title{
SEJARAH PERADILAN ISLAM DI NUSANTARA MASA KESULTANAN-KESULTANAN ISLAM PRA-KOLONIAL
}

\author{
Ismanto, Suparman \\ Dosen UIN SGD Bandung DPK pada STAI Fatahillah Serpong \\ Email: Suparmanjassin75@gmail.com
}

\begin{abstract}
What about the development of Islamic criminal law in Nusantara? This question should have been raised for the position of Islamic civil law is widely related to positive law, both as an influencing element or as a modification of religious norms formulated in civil law, even stated in the substantial legal scope of Law No.7 1989 dealing with religious justice. While Islamic law in the field of criminal justice - to mention another term of the Islamic criminal law - has not attracted much attention like the field of Islamic civil law. Apart from that, the available academic studies are often political in nature and broaden the distance between the understanding of positive criminal law and Islamic law in the field of criminal law. From a macro-historical perspective, the plurality of laws is inevitably a historical reality. The Positivism School believes that: the development of law is formalized for the sake of the law only. These circles strongly reject political interference in law, law by law, legal science in the form of value-free science while political science especially when associated with social science can be in the form of value-loaded science. According to this group's view, the procedure of finding, forming, and implementing law are in the hand of legal apparatus, the law can only be found through the judge's decision. The legal formation process is limited to legitimator products passed by the law. Law is a command of the law giver.
\end{abstract}

Keywords: Islamic Law, Islam Nusantara, Islamic Criminal Law, Legal Formation Process. 


\section{Pendahuluan}

Walaupun merupakan bagian integral syari'ah Islam dan memiliki peran signifikan, kompetensi dasar yang dimiliki hukum Islam, tidak banyak dipahami secara benar dan mendalam oleh masyarakat, bahkan oleh kalangan ahli hukum itu sendiri. Sebagian besar kalangan beranggapan, tidak kurang di antaranya kalangan muslim, menancapkan kesan kejam, incompatible dan off to date dalam konsep hukum Islam. Ketakutan ini semakin jelas adanya apabila mereka membincangkan hukum pidana Islam, ketentuan pidana potong tangan, rajam, salab dan qishas telah off to date dan sangat bertentangan dengan nilai-nilai kemanusian.

Hubungan antara praktek hukum Islam dengan agama Islam dapat diibaratkan dengan dua sisi mata uang yang tak terpisahkan. Hukum Islam bersumber dari ajaran Islam, sedangkan ajaran Islam adalah ajaran yang dipraktekkan pemeluknya. Oleh sebab itu, untuk membicarakan perkembangan hukum Islam di Indonesia erat hubungannya dengan penyebaran agama Islam di Indonesia. Oleh karena itu, amat wajar jika kajian kedudukan hukum Islam pra-kolonial dilakukan dengan asumsi bahwa tata hukum Islam Indonesia berkembang seiring dengan sampainya dakwah Islam di Indonesia.

\section{Periodisasi Peradilan Islam di Nusantara Masa Awal}

Sejarah pembentukan Pengadilan Agama di seluruh Indonesia pada masa penjajahan (Portugis, Belanda dan Jepang) harus dikaji berdasarkan sejarah masuknya Islam ke Indonesia pada abad XIII. Penyebaran agama Islam ke Indonesia melalui saudagar Arab dan Gujarat yang pada saat itu membuat kelompok masyarakat yang akhirnya berkembang menjadi Kerajaan Islam. Meskipun sudah ada hukum Islam, akan tetapi secara kelembagaan belum dikenal dengan istilah Pengadilan Agama.

Lambat laun proses konkordasi hukum Islam mempengaruhi adat kebiasaan setempat yang pada akhirnya meresipir hukum Islam sebagai Hukum Adat yang sulit dan kompleks untuk dikaji. Untuk menemukan istilah atau nama Pengadilan Agama di Indonesia pada masa Pra-Penjajahan. Pada abad ke-7, penerapan hukum Islam bukan hanya pada pelaksanaan ibadahibadah tertentu saja melainkan juga diterapkan pada masalah-masalah mu'amalah, munakahat, dan 'uqubat. Dalam hal penyelesaian masalah muamalah, munakahat, dan uqubat diselesaikan melalui Peradilan Agama. Walaupun secara Yuridis lembaga Peradilan Agama belum ada, tetapi dalam praktiknya telah ada penerapan Peradilan Agama dalam proses penyelesaian perkara-perkara tersebut.

Periodisasi peradilan Islam di Indonesia sebelum datangnya pemerintahan kolonial Belanda yang disepakati para ahli terbagi menjadi tiga periode, yaitu: 


\section{Periode Tahkim}

Pada masa awal Islam datang ke Nusantara, komunitas Islam sangat sedikit dan pemeluk Islam masih belum mengetahui tentang hal-hal yang berhubungan dengan Islam. Bila timbul permasalahan, mereka menunjuk seseorang yang di pandang ahli untuk menyelesaikannya. Apa pun keputusan yang akan dijatuhkan oleh orang yang ditunjuk itu keduannya harus taat untuk mematuhinya. Cara seperti inilah yang disebut "tahkim". Bertahkim seperti ini dapat juga dilaksanakan dalam hal lain sengketa, seperti penyerahan pelaksanaan akad nikah dari wanita yang tidak mempunyai wali.

\section{Periode Ahl al-Halli wa al-'Aqdi}

Setelah kelompok-kelompok masyarakat Islam terbentuk dan mampu mengatur tata kehidupan sendiri, pelaksanaan kekuasaan kehakiman dilaksanakan dengan cara mengangkat Ahl al-Hall wa al- 'Aqd. Yaitu orangorang yang terpercaya dan luas pengetahuannya untuk menjadi sesepuh masyarakat, selanjutnya Ahl al-Hali wa al- 'Aqd mengangkat para hakim untuk menyelesaikan segala sengketa yang ada di masyarakat. Penunjukkan ini dilakukan atas dasar musyawarah dan kesepakatan.

\section{Periode Tauliyah}

Setelah terbentuknya kerajaan-kerajaan Islam di Indonesia, pengangkatan hakim dilaksanakan dengan cara Tauliyah dari Imam, atau pelimpahan wewenang dari Sultan selaku kepala Negara, kepala Negara selaku Waliy al-Amri mempunyai wewenang mengangkat orang-orang yang telah memenuhi syarat tertentu untuk menjadi hakim di wilayah kerajaan yang ditentukan oleh kepala Negara atau sultan.

Bersamaan dan perkembangan masyarakat Islam, ketika kedatangan orang-orang Belanda pada $1605 \mathrm{M}$, Nusantara sudah terdiri dari sejumlah kerajaan Islam. Pada periode ini kerajaan-kerajaan Islam Nusantara sudah mempunyai pembantu jabatan agama dalam sistem pemerintahannya. Misalnya di tingkat desa ada jabatan agama yang disebut kaum, kayim, modin, dan amil. Di tingkat kecamatan di sebut Penghulu Naib. Di tingkat Kabupaten ada Penghulu Seda dan di tingkat kerajaan disebut Penghulu Agung yang berfungsi sebagai hakim atau (qadhi) yang dibantu beberapa penasihat yang kemudian disebut dengan pengadilan Serambi.

Pertumbuhan dan perkembangan Peradilan Agama pada masa kesultanan Islam bercorak majemuk. Kemajemukan itu sangat bergantung kepada proses Islamisasi yang dilakukan oleh pejabat agama dan ulama bebas dari kalangan pesantren; dan bentuk integrasi antara hukum Islam dengan kaidah lokal yang hidup dan berkembang sebelumnya. Kemajemukan peradilan itu terletak pada otonomi dan perkembangannya, yang berada dalam 
lingkungan kesultanan masing-masing. Selain itu, terlihat dalam susunan pengadilan dan hierarkinya, kekuasaan pengadilan dalam kaitannya dengan kekuasaan pemerintahan secara umum, dan sumber pengambilan hukum dalam penerimaan dan penyelesaian perkara yang diajukan kepadanya. ${ }^{1}$

Sebenarnya sebelum Islam datang ke Nusantara, di negeri ini telah dijumpai dua macam peradilan, yakni Peradilan Perdata dan Peradilan $P a d u .^{2}$ Peradilan Pradata mengurus masalah-masalah perkara yang menjadi urusan raja sedangkan Peradilan Padu mengurus masalah yang tidak menjadi wewenang raja. Pengadilan pradata apabila diperhatikan dari segi materi hukumnya bersumber hukum Hindu yang terdapat dalam pepakem atau kitab hukum sehingga menjadi hukum tertulis, sementara Pengadilan Padu berdasarkan pada hukum Nusantara asli yang tidak tertulis.

Menurut R. Tresna (1977: 17), dengan masuknya agama Islam di Nusantara, maka tata hukum di Nusantara mengalami perubahan. Hukum Islam tidak hanya menggantikan hukum Hindu, yang berwujud dalam hukum pradata, tetapi juga memasukan pengaruhnya dalam berbagai aspek kehidupan masyarakat pada umumnya. Meskipun hukum asli masih menunjukan keberadaannya, tetapi hukum Islam telah merembes di kalangan para penganutnya terutama hukum keluarga. Hal itu mempengaruhi terhadap proses pembentukan dan pengembangan Pengadilan Agama di Indonesia. ${ }^{3}$

Hukum Islam di Nusantara sebenarnya telah lama hidup di antara masyarakat Islam itu sendiri, hal ini tentunya berkaitan dengan pertumbuhan dan perkembangan agama Islam. Jika dilihat sebelum Islam masuk, masyarakat Indonesia telah membudaya kepercayaan animisme dan dinamisme. Kemudian lahirlah kerajaan-kerajaan yang masing-masing dibangun atas dasar agama yang dianut mereka, misalkan Hindu, Budha dan disusul dengan kerajaan/kesultanan Islam yang didukung para wali pembawa dan penyiar agama Islam.

Akar sejarah hukum Islam di kawasan Nusantara menurut sebagian ahli sejarah telah dimulai pada abad pertama hijriah, atau sekitar abad ke-7 dan ke-8 Masehi. Sebagai gerbang masuk ke dalam kawasan Nusantara, di kawasan utara pulau Sumatra lah yang dijadikan sebagai titik awal gerakan dakwah para pendatang muslim. Dan secara perlahan gerakan dakwah itu kemudian membentuk masyarakat Islam pertama di Peureulak, Aceh Timur. Berkembanganya komunitas muslim di wilayah itu kemudian diikuti dengan berdirinya kerajaan Islam pertama sekitar abad ke-13 yang dikenal dengan Samudera Pasai, terletak di wilayah Aceh Utara.

1 Cik Hasan Bisri, MS., Peradilan Agama di Indonesia, PT. Raja Grafindo Persada, Jakarta, 2003, Cet: 4, hal. 113.

2 Abdul Halim, Peradilan Agama dalam Politik Hukum Islam, PT. Raja Grafindo Persada, Jakarta, 2000, hal. 34.

3 Cik Hasan Bisri, Op. Cit., hal.113. 
Dengan berdirinya kerajaan Samudera Pasai itu, maka pengaruh Islam semakin menyebar dengan berdirirnya kerajaan lainnya seperti kesultanan Malaka yang tidak jauh dari Aceh. Selain itu ada beberapa yang ada di Jawa antara lain kesulatanan Demak, Mataram, dan Cirebon. Kemudian di daerah Sulawesi dan Maluku yang ada kerajaan Gowa dan kesultanan Ternate serta Tidore.

Hukum Islam pada masa ini merupakan sebuah fase penting dalam sejarah hukum Islam di Nusantara. Dengan adanya kerajaan-kerajaan Islam menggantikan kerajaan Hindu-Budha berarti untuk pertama kalinya hukum Islam telah ada di Nusantara sebagai hukum positif. Hal ini terbukti dengan fakta-fakta dan adanya literatur-literatur fiqih yang ditulis oleh para ulama Nusantara pada abad ke-16 dan 17-an. Dimana para penguasa ketika itu memposisikan hukum Islam sebagi hukum Negara.

Islam menjadi pilihan bagi masyarakat karena secara teologis ajarannya memberikan keyajinan dan kedamaian bagi penganutnya. Masyarakat pada periode ini dengan rela dan patuh, tunduk dan mengikuti ajaran-ajaran Islam dalam berbagai dimensi kehidupan. Namun keadaan itu kemudian menjadi terganggu dengan datangnya kolonialisme barat yang membawa misi tertentu, mulai dari misi dagang, politik bahkan sampai misi kristenisasi. $^{4}$

\section{Peradilan Islam Masa Kesultanan-kesultanan Islam}

Bersamaan dengan perkembangan masyarakat Islam, ketika Nusantara terdiri dari sejumlah kerajaan/ kesultanan Islam maka, dengan penerimaan Islam dalam kerajaan, otomatis para hakim yang melaksanakan keadilan diangkat oleh sultan atau imam. Berikut akan dijelaskan sejarah peradilan pada masing-masing kerajaan/ kesultanan di Indonesia. ${ }^{5}$

\section{Kerajaan Samudera Pasai}

Islam masuk ke Indonesia sekitar abad ke-13 dan 14 Masehi yang di mulai di kerajaan Samudera Pasai. Penyiaran Islam ini di bawa oleh para pedagang-pedagang dari Hadramaut dan Gujarat India dan sebagian kecil dari orang-orang Persia. Perkembangan Islam pada masa ini lebih dominan di daerah-daerah pesisir pantai yang lebih dekat dengan pelabuhan sedangkan di daerah-daerah pedalaman Islam lebih sedikit karena terbatasnya transportasi pada saat itu.

Sejarah Islam mencatat Samudera Pasai adalah kerajaan Islam pertama di Indonesia. Kerajaan ini berdiri setelah Rajendra I dari India 1020-1024 tidak berhasil menundukkan daerah itu. Pada saat Raja kehilangan simpati

4 Ahmad Rofiq, Hukum Islam di Indonesia, PT Raja Grafindo Persada, Jakarta, 1998, h. 37. 5 Abdul Halim, Op. Cit., hal. 38. 
penduduk setempat sehingga menyebabkan kekalahannya. Tercatat Malikus Saleh adalah raja yang menduduki tahta. Raja inilah yang pertama kali sebagai penguasa beragama Islam, dengan kerajaannya yang bernama Samudera Pasai.

Kerajaan ini adalah salah satu kerajaan Islam yang menerapkan hukum pidana Islam. Menurut Hamka, dari Pasailah dikembangkan paham Syafi'i ke kerajaan-kerajaan Islam lainnya di Indonesia, bahkan setelah kerajaan Islam Malaka berdiri (1400-1500 M) para ahli hukum Islam Malaka datang ke Samudera Pasai untuk meminta kata putus mengenai berbagai masalah hukum yang mereka jumpai dalam masyarakat.

Pelaksanaan hukum Islam menyatu dengan pengadilan dan diselenggarakan secara berjenjang. Tingkat pertama dilaksanakan oleh pengadilan tingkat kampung yang dipimpin oleh keuchik. Pengadilan itu hanya menangani perkara-perkara ringan sedangkan pengadilan tingkat pertama dapat mengajukan banding kepada ulee balang (pengadilan tingkat kedua). Selanjutnya dapat di lakukan banding kepada Sultan yang pelaksanaannya dilakukan oleh Mahkamah Agung yang keanggotaannya terdiri atas Malikul Adil, Orang Kaya Sri Paduka Tuan, Orang Kaya Raja Bandhara, dan Faqih (ulama).

Pelaksanaan hukum pidana Islam di telah dilaksanakan dikerajaan ini, seperti pelaksanaan hukuman rajam untuk Meurah Pupoek, seorang anak raja yang terbukti melakukan zina. Pelaksanaan hukum Islam pada kerajaan ini tidak mengenal jabatan atau golongan, mulai dari keluarga kerajaan sampai rakyat biasa apabila terbukti melanggar hukum Islam pasti akan mendapatkan hukuman yang setimpal dengan perbuatannya.

Hirarki Peradilan pada di kerajaan Samudera Pasai:

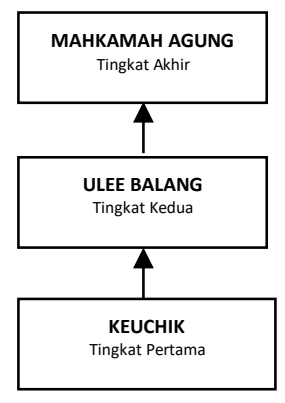

2. Peradilan Agama Islam di Kerajaan/ Kesultanan Mataram

Kerajaan Islam yang paling penting di Jawa adalah Demak (yang kemudian diganti oleh Mataram), Cirebon dan Banten. Di Indonesia timur yang paling penting adalah Goa di Sulawesi Selatan dan Ternate yang pengaruhnya luas hingga kepulauan Filipina, di Sumatra yang paling penting adalah Aceh yang wilayahnya, meliputi wilayah Melayu. Keadaan terpencar 
kerajaan-kerajaan Indonesia dan hubungannya dengan negara-negara tetangga, Malaysia dan Filipina. ${ }^{6}$

Sebelum Sultan Agung menjadi Sultan Mataram, hukum Islam tidak banyak berpengaruh di kalangan kerajaan. Banyak di antara mereka memeluk agama Hindu. Pada masa Sultan Agung memerintah (1613-1645), hukum Islam hidup dan berpengaruh besar di kerajaan itu. Pernyataan ini dapat dibuktikan dengan berubahnya tata hukum di Mataram, yang mengadili perkara-perkara yang membahayakan keselamatan kerajaan. Istilah pengadilan untuk ini adalah Kisas. Satu istilah yang sebenarnya dalam bahasa aslinya. Kerajaan ini tidak sepenuhnya menerapkan hukum pidana Islam. Hukum pidana hanya diterapkan dalam masalah Bughah (pemberontakan).

Dengan munculnya Mataram menjadi kesultanan/kerajaan Islam, di bawah pemerintahan Sultan Agung mulai diadakan perubahan dalam sistem peradilan dengan memasukkan unsur hukum dan ajaran agama Islam dengan cara memasukkan orang-orang Islam ke dalam Peradilan Peradaban. Namun, setelah kondisi masyarakat dipandang siap dan paham dengan kebijakan yang diambil Sultan Agung, maka kemudian paradilan pradata yang ada diubah menjadi Paradilan Surambi dan lembaga ini tidak secara langsung berada dibawah raja, tetapi dipimpin oleh ulama. Ketua pengadilan meskipun pada prinsipnya di tangan sultan, tetapi dalam pelaksanaannya berada di tangan penghulu yang didampingi beberapa orang ulama dari lingkungan pesantren sebagai anggota majelis. Sultan tidak pernah mengambil keputusan yang bertentangan dengan nasihat Peradilan Surambi.

Meski terjadi perubahan nama dari Pengadilan

Pradata menjadi Pengadilan Surambi, namun wewenang kekuasaannya masih tetap seperti peradilan pradata. Ketika Amangkurat I menggantikan Sultan Agung pada tahun 1645, peradilan pradata dihidupkan kembali untuk mengurangi pengaruh ulama dalam pengadilan dan raja sendiri yang menjadi tampuk kepimpinannya. Namun dalam perkembangan berikutnya pengadilan Surambi masih menunjukkan keberadaannya sampai pada masa penjajahan Belanda, meskipun dengan kewenangan yang terbatas. Menurut Snouck (1973: 21) pengadilan tersebut berwenang menyelesaikan perselisihan dan persengketaan yang berhubungan dengan hukum kekeluargaan, yaitu perkawinan dan kewarisan. ${ }^{7}$

Hierarki Peradilan di Kerajaan/ kesultanan Mataram

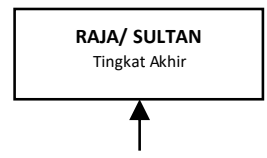

6 Ibid., hal. 38-39.

7 Cik Hasan Bisri, Op. Cit., hal. 114. 


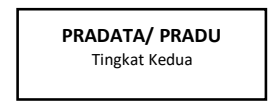

Pengadilan Surambi atau Hukum Dalem Ing Surambi di Yogyakarta diketuai oleh seorang penghulu yang disebut penghulu hakim. Sebagai ketua ia memperoleh gelar dari Sultan: Kyai Pengulu. Kemungkinan yang menjadi penghulu pertama di Yogyakarta yang diserahi tanggungjawab masjid adalah Kyai Penghulu Seh Abodin. ${ }^{8}$

Dalam melaksanakan tugasnya menangani masalah-masalah yang ada di masyarakat, penghulu hakim dibantu oleh empat orang anggota disebut pathok nagara atau dalam bahasa halus pathok nagari. Baik penghulu hakim maupun pathok nagara termasuk abdi dalem. Dalam perkembangan selanjutnya susunan keanggotaan ini ditambah adanya beberapa khotib yang bertugas memberi khotbah di beberapa masjid pada hari Jumat. Adapun kitab hukum yang dipakai sebagai acuan di samping Al Quran dan Hadits adalah kitab-kitab fiqih yaitu Kitab Muharrar, Mahali, Tuhpah (baca: Tuhfah), Patakulmungin (Fathulmu'in) dan Patakulwahab (Fat-hulwahab). Apabila benar demikian, maka tugas penghulu hakim dan anggota-anggotanya yaitu pathok nagara dengan abdi dalem di bidang hukum, keagamaan, di masyarakat sungguh tidak ringan.

Sebutan pathok nagara di kalangan Reh Kawedanan Pangulon Karaton Ngayogyakarta (semacam Departemen Agama) merupakan jabatan abdi dalem di lembaga tersebut, dan tepatnya pembantu penghulu hakim di Pengadilan Surambi. Istilah tersebut dalam bahasa Jawa terdiri dari dua kata; pathok dan nagara. Dalam kamus Baoesastra Djawa oleh W.J.S. Poerwodarminta, ${ }^{9}$ pathok (patok) artinya yaitu:

1) sesuatu benda yang dapat ditancapkan baik berupa kayu, bambu dan lain-lain, dengan maksud untuk batas, tanda, dan sebagainya.

2) bersifat tetap tidak dapat ditawar-tawar lagi, tempat para peronda berkumpul, sawah yang pokok,

3) - an artinya angger-angger, paugeran atau aturan, dasar hukum.

Sedangkan nagara berarti negara, kerajaan, atau pemerintahan. Pathok nagara atau dalam bahasa Jawa halus pathok nagari, secara harafiah dapat berarti batas negara, namun juga dapat berarti 'aturan (yang dianut oleh) negara', dasar hukum negara. Suatu contoh kata angger berkaitan dengan hukum, pada masa itu ada kitab Angger Sepuluh atau Angger Sedasa merupakan undang-undang yang mengatur tentang adminstrasi dan agraria, demikian juga serat angger-angger yang lain.

8 G.P. Rouffaer. Vorstenlanden. Overdruk Uit Adatrechbundel XXXV, serie D, 1931, hlm. 105.

9 W.J.S. Poerwodarminta. Baoesastra Djawa. J.B. Wolters, Uitgevers Maatschappij NV, Groningen-Batavia, 1939, hal. 479. 
Berkaitan dengan lembaga hukum tersebut, pada awal berdirinya Karaton Ngayogyakarta Hadiningrat tahun 1755, mempunyai lembaga hukum bernama Pengadilan Surambi (Hukum Dalem Ing Surambi) yang juga dipunyai oleh Surakarta. Di Yogyakarta lembaga ini diketuai penghulu hakim, dibantu oleh empat orang anggota bernama pathok nagara yang di Surakarta bernama Ngulama. Pada perkembangan selanjutnya, susunan keanggotaan Pengadilan Surambi tersebut kemudian ditambah adanya ketib-ketib (baca: khotib), sebagai pembantu yang akhirnya menjadi anggota pula sehingga menjadi 10 orang.

Menurut catatan arsip Kawedanan Reh Pangulon, pathok nagara merupakan jabataan (abdi dalem) rendah di suatu lembaga peradilan yang diberikan oleh raja (Sultan) kepada seseorang yang dipercaya mampu menguasai bidang hukum agama Islam atau syariah. Tidak diketahui secara pasti kenapa sebutan jabatan tersebut demikian. Penulis hanya dapat menduga bahwa hal itu berkaitan dengan keberadaannya di lembaga hukum (agama) yang berlaku di saat itu. Keberadaannya di masyarakat sebagai tokoh panutan, sebagai kepanjangan aturan raja yang memerintah negari (keprajan) Yogyakarta. Walaupun jabatan rendah, namun abdi dalem pathok nagara mempunyai peranan penting dalam pemerintahan saat itu, karena langsung berhadapan dengan masyarakat yang penuh dengan berbagai macam permasalahan.

Sesuai dengan peranan dan tugasnya yang menyangkut kehidupan masyarakat kasultanan berdasarkan agama pada masa itu, maka sebagai abdi dalem pathok nagara pembantu penghulu hakim, harus membekali dirinya dengan pengetahuan agama. Ia mempunyai kewajiban mencerdaskan masyarakat di bidang kehidupan beragama dan bermasyarakat.

Perlu diketahui bahwa pada masa itu masa penjajahan Belanda, sehingga raja perlu membentengi rakyatnya secara jiwani, supaya berkepribadian kuat. Untuk syiar agama Islam ini maka di berbagai daerah di wilayah didirikanlah masjid-masjid yang kemudian disebut masjid kagungan dalem yang berarti masjid milik raja atau sering disebut Masjid Sulthoni. Menurut catatan Kawedanan Pangulon Keraton Yogyakarta (1981), masjid kagungan dalem di Daerah Istimewa Yogyakarta ada 78 buah, baik di dalam kota maupun yang tersebar di daerah-daerah Kabupaten Sleman, Gunungkidul, Kulonprogo dan Bantul. Dalam arsip kraton yang tersimpan di Perpustakaan Widyabudaya, pathok nagara abdi dalem Kawedanan Pangulon Kasultanan Yogyakarta oleh Sultan ditempatkan di Mlangi Kabupaten Sleman (barat), Plosokuning Kabupaten Sleman (utara), Dongkelan Kabupaten Bantul (selatan) dan Babadan Yogyakarta (timur).

Pada masa pendudukan Balatentara Jepang (1942-1945), Babadan ini pernah direncanakan akan dijadikan tempat amunisi untuk keperluan perang Jepang, sehingga banyak penduduk yang pindah ke arah utara, kampung 
Kentungan, demikian juga masjidnya. Akan tetapi rencana tersebut tidak jadi dan penduduk kembali ke Babadan semula, masjidnya pun dibangun lagi. Di tempat-tempat ini pathok nagara yang termasuk abdi dalem Reh Kawedanan Pangulon bertanggung jawab atas kehidupan keagamaan dalam masyarakat dan kemakmuran masjid 'milik raja' (masjid kagungan dalem) yang ditanganinya.

Walaupun jumlah masjid kagungan dalem banyak, namun hanya empat masjid itulah yang ditangani oleh pathok nagara. Dalam memakmurkan masjid, ia dibantu oleh khotib, muadzin, merbot, barjama'ah dan ulu-ulu. Tidak ada keterangan-keterangan yang pasti kenapa keempat abdi dalem pathok nagara itu ditempatkan di Mlangi, Plosokuning, Dongkelan dan Babadan. Apabila dilihat dari pusat kerajaan keempat desa itu berada di barat, utara, selatan dan timur. Di pusat kerajaan sendiri ada Masjid Agung sebagai masjid kerajaan yang berdekatan dengan bangunan kraton. Ada kebiasaan orang Jawa, menurut imajinasinya bahwa jumlah 4 (empat) letaknya di dalam sebuah ruang, masing-masing menempati mata angin utama yang mengelilingi suatu titik pusat. Hal ini juga terungkap dalam susunan lembaga pemerintahan, satu ada di tengah-tengah sebagai kepala ditambah 4 (empat) berada di sekelilingnya sebagai pembantu utama. Sebagai contohnya pemerintahan pada masa kerajaan Mataram-Islam, apabila raja duduk di singgasana, dihadap para pegawainya (abdi dalem) duduk membentuk lingkaran-lingkaran konsentris. ${ }^{10}$

Menilik kebiasaaan orang Jawa yang 'suka' serba empat mengelilingi satu pusat, ada kemiripan dengan letak-letak masjid milik raja yang menjadi tanggungjawab pathok nagara. Bukankah mereka itu abdi yang bertugas membantu penghulu hakim sebagai ketua Pengadilan Surambi. Pertanyaan mengenai jumlah abdi dalem pathok nagara yang membantu penghulu hakim di Pengadilan Surambi hanyalah empat, kemungkinan ada kaitannya dengan konsep konsentris seperti yang ada di kerajaan-kerajaan Jawa masa lalu.

Telah disebutkan bahwa abdi dalem pathok nagara bertanggungjawab terhadap masjid yang ditanganinya. Begitu eratnya antara masjid pathok nagara ini sehingga terucap oleh masyarakat masjid-masjid tadi sebagai masjid pathok nagara. Ucapan tersebut tidaklah salah, karena sebenarnya mengandung maksud masjid kagungan dalem yang menjadi tanggungjawab pathok nagara. Oleh karena itu tidaklah mengherankan di sekitar tempat tersebut sampai kini masih ada pesantren, tempat belajar agama Islam.

Setelah kemerdekaan keadaan menjadi berubah. Kerajaan-kerajaan yang semula mempunyai 'kekuasaan' (walaupun masih juga di bawah kekuasaan penjajah) dengan sendirinya masuk ke satu wadah karena telah terbentuk Negara Kesatuan Republik Indonesia. Kasultanan Yogyakarta juga

10 Robert Heine Gelderen, Konsepsi Tentang Negara dan Kedudukan Raja di Asia Tenggara (Terjemahan Deliar Noer), CV. Rajawali, Jakarta, 1972, hal. 11-12. 
Kadipaten Pakualaman meleburkan daerahnya ke wilayah Republik Indonesia. Walaupun Republik Indonesia baru berdiri namun sebagai negara harus mempunyai dasar negara, Undang-Undang Dasar juga kebijakankebijakan lainnya. Peraturan atau undang-undang pemerintah pendudukan sedikit demi sedikit dirubah, termasuk di bidang peradilan.

Selanjutnya pada tanggal 29 Agustus 1947 Pemerintah Republik Indonesia mengeluartkan UU No 23 Tahun 1947 tentang Penghapusan Pengadilan Raja (Zelfbestuursrecht-spraak) di Jawa dan Sumatera. Di dalamnya menyebutkan bahwa semua pengadilan raja diserahkan kepada pengadilan yang berwenang (Republik Indonesia). Dengan demikian sejak diberlakukan UU tersebut maka secara yuridis Pengadilan Surambi telah hapus. Walaupun tidak mempunyai kewenangan di lembaga peradilan, namun penghulu hakim dan pathok nagara secara adat masih tetap sebagai abdi dalem di Reh Kawedanan Pangulon. Di sini kawedanan semacam departemen dan Kawedanan Pangulon mengurusi masalah keagamaan, masalah ukhrawi. Semenjak itu pula tidak ada lagi pengangkatan abdi dalem pathok nagara, namun demikian masjidnya masih ada dan dimanfaatkan sampai sekarang.

\section{Peradilan Islam di Kerajaan/ Kesultanan Aceh dan Banjar}

Di Aceh, sistem peradilan yang berdasarkan hukum Islam menyatu dengan pengadilan negeri, yang mempunyai tingkatan-tingkatan;

(a) Dilaksanakan di tingkat kampung yang dipimpin keucik. Peradilan ini hanya menangani perkara-perkara yang tergolong ringan. Sedangkan perkara-perkara berat diselesaikan oleh Balai Hukum Mukim

(b) Apabila yang berperkara tidak puas dengan keputusan tingkat pertama, dapat mengajukan banding ke tingkat yang ke dua yakni Oeloebalang.

(c) Bila pada tingkat Oeloebalang juga dianggap tidak dapat memenuhi keinginan pencari keadilan, dapat mengajukan banding ke pengadilan tingkat ke tiga yang disebut panglima sagi.

(d) Seandainya keputusan panglima sagi tidak memuaskan masih dapat mengajukan banding kepada sultan yang pelaksanaannya oleh Mahkamah agung yang terdiri anggotanya malikul adil, orang kaya sri paduka tuan, orang kaya raja bandara, dan fakih (ulama). Sitem peradilan di Aceh sangat jelas menunjukkan hirarki dan kekuasaan absolutnya. ${ }^{11}$

4. Pengadilan Agama di Kerajaan Banjar

Kapan masuknya Islam ke kerajaan Banjar atau Kalimantan Selatan tidak ada yang dapat menetapkan dengan pasti. Namun demikian setidaknya masuk dan berkembangnya Islam di Kalimantan Selatan dapat terjadi pada abad ke-16.

11 Ibid., hal. 115. 
Pidana murni dilaksanakan di kerajaan ini, hal ini terbukti dengan adanya hukum potong tangan bagi siapa saja yang mencuri dan hukuman rajam bagi siapa saja yang melakukan zina. Kerajaan Banjar tercatat sebagai suatu kerajaan besar yang memeluk Islam.

Awal KeIslaman itu mulanya tentu dari seorang ke orang lain, tetapi akhirnya menemukan penyebaran yang mantap adalah ketika masuk Islamnya Sultan Banjar, yang sebelumnya bernama Pangeran Samudera berganti nama menjadi Pangeran Suriansyah. Pangeran Samudera menjanjikan dirinya akan masuk Islam, jika menang berperang melawan pamannya Pangeran Tumenggung, setelah mendapat bantuan dari kerajaan di Jawa.

Dengan masuk Islamnya raja, perkembangan selanjutnya tidak begitu sulit, karena ditunjang oleh fasilitas serta kemudahan lainnya yang akhirnya membawa kepada kehidupan masyarakat Banjar yang benar-benar bersendikan Islam. Namun demikian juga seperti sebagian masuknya Islam di Indonesia, yang datangnya lebih belakang dari agama Hindu, maka konsepsi hukum yang dianut di kerajaan Banjar inipun nampaknya juga tidak murni berdasarkan Qur'ân dan As-Sunnah. Di Kalimantan Selatan, Sebelum kehadiran Islam juga subur adat istiadat lama yang sifatnya animisme, ini merupakan tantangan para pendakwah yang tak kenal lelah untuk mengikis setiap hadirnya ajaran yang bertentangan dengan Islam.

Kehidupan keagamaan diwujudkan dengan adanya mufti-mufti dan qadhi-qadhi, ialah hakim serta penasehat kerajaan dalam bidang agama. Dalam tugas mereka, terutama adalah menangani masalah-masalah berkenaan dengan hukum keluarga dan hukum perkawinan. Demikian pula Qadhi, di samping menangani masalah-masalah hukum privat, teristimewa juga menyelesaikan perkara-perkara pidana atau dikenal dengan Had. Tercatat dalam sejarah Banjar, diberlakukannya hukum bunuh terhadap orang Islam yang murtad, hukum potong tangan untuk mencuri, dan mendera siapa saja yang kedapatan melakukan zina.

Bahkan dalam tatanan hukum kerajaan Banjar telah dikodifikasikan dalam bentuk sederhana, aturan-aturan hukum yang sepenuhnya berorientasi kepada hukum Islam, kodifikasi itu dikenal kemudian dengan UndangUndang Sultan Adam. Pada akhirnya kedudukan Sultan di Banjar bukan hanya sebagai pemegang kekuasaan dalam kerajaan, tetapi lebih jauh diakui sebagai 'Ulul Amri kaum muslimin di seluruh kerajaan.

Pengadilan Agama di kawasan Banjar pada masa kesultanan misalnya, hal ini bisa kita lihat pada biografi Datu Abulung. Beliau di hukum mati oleh sultan karena menyebarkan ajaran wahdatul wujud. Alasan Sultan Tahmidullah menghukum mati setelah sultan bermusyawarah dengan para ulama dan mereka berkesimpulan bahwa: Atas dasar kepentingan keselamatan orang banyak dan tugas seorang pemimpin adalah untuk keselamatan akidah dan kemaslahatan rakyatnya; menolak kerusakan lebih didahulukan dari 
mendatangkan kebaikan dan tugas seorang pemimpin terhadap rakyatnya dipusatkan untuk mendatangkan kebaikan maka sultan memutuskan untuk menghukum mati beliau. ${ }^{12}$

Disini kita bisa melihat bahwa perkara seperti "penodaaan agama" bisa dihukum mati dan sistem Pengadilan Agama yang berlaku di masyarakat Banjar saat itu diputuskan melalui musyawarah Sultan dan para ulama. Begitu pula masalah ibadah menjadi wewenang Pengadilan Agama.

Dalam biografi Datu Sanggul diceritakan bahwa sepeninggal Datu Suban guru beliau, beliau tidak pernah lagi shalat jum'at di Masjid Muning. Hal ini disebabkan karena dengan karomah beliau, beliau bisa shalat jum'at langsung di Masjidil Haram, walaupun shalat selain shalat Jum'at beliau tetap berjamaah di Masjid tersebut. Tapi karena pada masa itu diberlakukan perintah sultan yang menyatakan barang siapa yang tidak melaksanakan shalat fardhu Jum'at berjamaah akan didenda maka beliau harus membayar denda yang telah ditetapkan raja.

Selain itu, adanya Undang-Undang Sultan Adam yang terdiri dari 31 pasal yang berisi tentang hukum Islam, hukum acara Peradilan Islam, hukum agraria, hukum fiskal, hukum pidana, hukum perdagangan, dan lain-lain 3 juga menjadi bukti lainnya, karena siapakah yang menyidang seandainya terjadi pelanggaran, tentunya Pengadilan Agama, walaupun sistem yang berlaku di Pengadilan Agama dulu dengan sekarang berbeda, tapi esensinya tetap sama, bahkan Pengadilan Agama pada masa itu mempunyai wewenang yang lebih luas dibandingkan Pengadilan Agama zaman sekarang.

\section{Peradilan Agama Islam di Priangan}

Tak hanya di daerah kekuasan Sultan Agung saja, tetapi di pesisir sebelah utara Jawa, utamanya di Cirebon hukum Islam utamanya yang berhubungan dengan masalah-masalah kekeluargaan amat banyak berpengaruh. Tercatat di Priangan misalnya, adanya Pengadilan-pengadilan Agama yang mengadili perkara yang dewasa ini masuk kepada masalahmasalah subversif. Pengadilan ini merupakan suatu peradilan yang mengambil pedoman kepada rukun-rukun yang ditetapkan oleh penghulu, yang tentu saja adalah pemuka-pemuka agama di kerajaan.

Sistem pengadilan di Cirebon dilaksanakan oleh tujuh orang Menteri yang mewakili tiga Sultan, yaitu Sultan Sepuh, Sultan Anom, dan Panembahan Cirebon. Segala acara yang menjadi sidang itu diputuskan menurut Undang-Undang Mataram, Jaya Lengkara, Kontra Menawa dan Adilullah. Namun demikian, satu hal yang tidak dapat dipungkiri, bahwa kedalam Papakem Cirebon itu telah tampak adanya pengaruh hukum Islam.

12 Ahmadi Hasan, Adat Badamai Interaksi Hukum Islam dan Hukum Adat pada Masyarakat Banjar, Antasari Press, Banjarmasin, 2009, h. 123. 
Di Cirebon atau Priangan terdapat tiga bentuk peradilan; Peradilan Agama, Peradilan Drigama, dan Peradilan Cilaga. Kompetensi Peradilan Agama adalah perkara-perkara yang dapat dijatuhi hukuman badan atau hukum mati, yaitu yang menjadi absolut kompetensi peradilan pradata di Mataram. Perkara-perkara tidak lagi dikirim ke Mataram, karena belakangan kekuasaan pemerintah Mataram telah merosot. Kewenangan absolut Peradilan Drigama adalah perkara-perkara perkawinan dan waris. Sedangkan Peradilan Cilaga khusus menangani sengketa perniagaan. Pengadilan ini dikenal dengan pengadilan wasit. ${ }^{13}$

\section{Peradilan Agama Islam di Banten}

Sementara itu di Banten pengadilan disusun menurut pengertian Islam. Pada masa sultan Hasanuddin memegang kekuasaan, pengaruh hukum Hindu sudah tidak berbekas lagi. Karena di Banten hanya ada satu pengadilan yang dipimpin oleh Qodli sebagai hakim tunggal. Lain halnya dengan Cirebon yang pengadilannya dilaksanakan oleh tujuh orang menteri yang mewakili tiga sultan yaitu Sultan Sepuh, Sultan Anom dan Panembahan Cirebon kitab hukum yang digunakan adalah pepakem Cirebon, yang merupakan kumpulan macam-macam Hukum Jawa Kuno, memuat Kitab Hukum Raja Niscaya, Undang-Undang Mataram, Jaya Lengkara, Kontra Menawa dan Adidullah. Namun satu hal yang tidak dipungkiri bahwa pepakem Cirebon tanpa adanya pengaruh hukum Islam. ${ }^{14}$

Belanda pertama kali menginjakan kakinya di pelabuhan Banten pada tahun 1596. Bagaimana mulai berjalannya Peradilan Agama di sana dan bagaimana sikap Belanda terhadap Peradilan Agama di daerah ini, kiranya perlu diketahui bagaimana awal masuknya Islam di Banten. Setelah kota Banten, salah satu kota pelabuhan dari kerajaan Pakuan-Pajajaran dapat dikuasai oleh Falatehan, segeralah dibentuk pemerintahan atas nama Sultan Demak. Tak lama kemudian dapat dikuasai pula Sunda Kelapa, juga salah satu kota pelabuhan dari Pakuan-Pajajaran, yang kemudian diberi nama Jayakarta dan dijadikan wilayah dari kesultanan Banten. Cirebon sebagai kota pelabuhan terakhir dari Pakuan-Pajajaran diduduki pula ole Falatehan, selaku abdi dari Sultan Demak dalam rangka penyebaran agama Islam, sehingga Banten, Sunda Kelapa, dan Cirebon menjadi wilayah kekuasaan Demak.

Pada tahun 1552 Falatehan pindah ke Cirebon dan terus memerintah daerah ini, sedang pemerintahan di Banten diserahkan kepada putera sulungnya Hasanudin. Pada tahun 1568 Hasanudin menyatakan kesultanan Banten sebagai negara merdeka, bebas dari kekuasaan Demak, dan mulai mengatur pemerintahannya sendiri. Di antaranya menata pelaksanaan 
peradilan di kesultanan tersebut. Orang-orang Banten, sebelum kekuasaan negara direbut oleh Falatehan sudah mulai masuk Islam. Hal itu dipermudah oleh karena syahbandar di Banten dan yang memerintah kota itu atas nama Prabu Siliwangi, sudah lebih dahulu memeluk agama Islam. Orang-orang Banten, sebagai orang yang baru saja memeluk agama Islam amatlah giat dalam menjalankan agamanya dan memegang teguh pada hukum Islam.

Meskipun Cirebon didirikan hampir bersamaan dengan kesultanan Banten, akan tetapi lapisan atas dari penduduk Cirebon, yang berasal dari Demak, masih kokoh terikat dengan norma-norma hukum dan adat kebiasaan Jawa-kuno. Hal tersebut berpengaruh pada perkembangan peradilan di dua kesultanan tersebut. Pengadilan di Banten disusun menurut pengertian Islam. Pengadilan yang pernah ada dan berjalan berdasar pada hukum Hindu sebagai bentukan dari kerajaan Pakuan-Pajajaran, diwaktu Sultan Hasanudin memegang kekuasaan sudah tidak nampak lagi bekas-bekasnya sedikitpun. Pada abad ke-17 di Banten hanya ada satu macam pengadilan, yaitu yang dipimpin oleh Kadhi sebagai hakim tunggal.

Kalau pada abad ke-17 kesultanan Banten sudah sempurna menerapkan hukum Islam, maka pada awal abad ke-17 penguasa kerajaan Mataram baru masuk agama Islam. Akan tetapi dengan masuknya penguasa kerajaan Mataram ke dalam agama Islam pada permulaaan abad ke-17 tersebut penyebaran Islam hampir meliputi sebagian besar wilayah Indonesia karena wilayah kekuasaan kerajaan Mataram hampir meliputi seluruh wilayah Indonesia.

\section{Peradilan Agama Islam di Sulawesi}

Di Sulawesi integrasi ajaran Islam dan lembaga-lembaganya dalam pemerintahan kerajaan dan adat lebih lancar karena peranan raja. Di Sulawesi, kerajaan yang mula-mula menerima Islam dengan resmi adalah kerajaan Tallo di Sulawesi Selatan. Kemudian disusul oleh kerjaan Goa yang merupakan kerajaan terkuat dan mempunyai pengaruh di kalangan masyarakatnya.

Sementara itu di beberapa wilayah lain; seperti Kalimantan Selatan dan Timur, dan tempat-tempat lain, para hakim agama di angkat sebagai penguasa setempat. ${ }^{15}$ Dengan berbagai ragam pengadilan itu, menunjukan posisinya yang sama, yaitu sebagai salah satu pelaksana kekuasaan raja atau sultan. Di samping itu pada dasarnya batasan wewenang Pengadilan Agama meliputi bidang hukum keluarga, yaitu perkawinan dan kewarisan. Dengan wewenang demikian, proses pertumbuhan dan perkembangan pengadilan pada berbagai kesultanan memiliki keunikan masing-masing. Dan fungsi sultan pada saat itu adalah sebagai pendamai apabila terjadi perselisihan hukum.

15 Abdul Halim, Op. Cit., hal. 45. 
Di Sulawesi integrasi ajaran Islam dan lembaga-lembaganya dalam pemerintah kerajaan dan adat lebih lancar karena peranan raja. Melalui kekuasaan politik dalam struktur kerajaan ditempatkan Parewa Syara' (pejabat syari'at) yang berkedudukan sama dengan Parewa Adek (pejabat adek) yang sebelum datangnya Islam telah ada (pengadilan tingkat II). Parewa syara' dipimpin oleh Kali (Kadli), yaitu pejabat tertinggi dalam syariat Islam yang berkedudukan di pusat kerajaan (pengadilan tingkat III). Di masing-masing Paleli diangkat pejabat bahwan yang disebut imam serta dibantu oleh seorang khatib dan seorang Bilal (Pengadilan tingkat I). Para Kadi dan pejabat urusan ini diberikan gaji yang diambilkan dari zakat harta, sedekah Idul Fitri dan Idul Adha, kenduri kerajaan, penyelenggaraan mayat dan penyelenggaraan pernikahan. Hal ini terjadi pada saat pemerintahan raja Gowa XV (1637-1653) ketika Malikus Said berkuasa. Sebelumnya raja Gowa sendiri yang menjadi hakim agama Islam.

Hirarki Peradilan pada Kerajaan Sulawesi

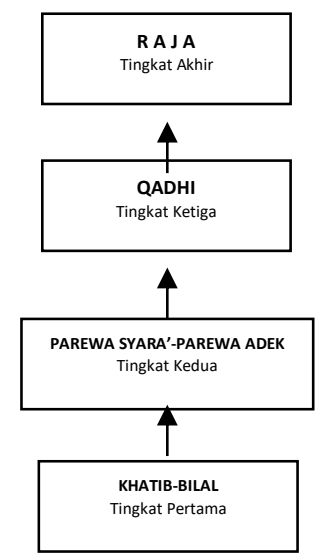

8. Kerajaan Raja Ali Haji di Riau

Sistem peradilan pada kerajaan Riau telah tertata dengan rapi pada masa Raja Ali. Lembaga peradilan mempunyai kelengkapan layaknya sebuah pengadilan di masa sekarang. Peradilan terdiri dari, Mahkamah Kerajaan yang bertugas menyelesaikan sengketa dalam kerajaan dan Mahkamah Kecil yang bertugas menangani setiap permasalahan yang timbul dalam masyarakat. Untuk masing-masing mahkamah itu diangkat tiga orang Qadhi yang menangani perkara mu'amalah, jinayah dan munakahat. 
Struktur Lembaga Peradilan Kerajaan Raja Ali Haji

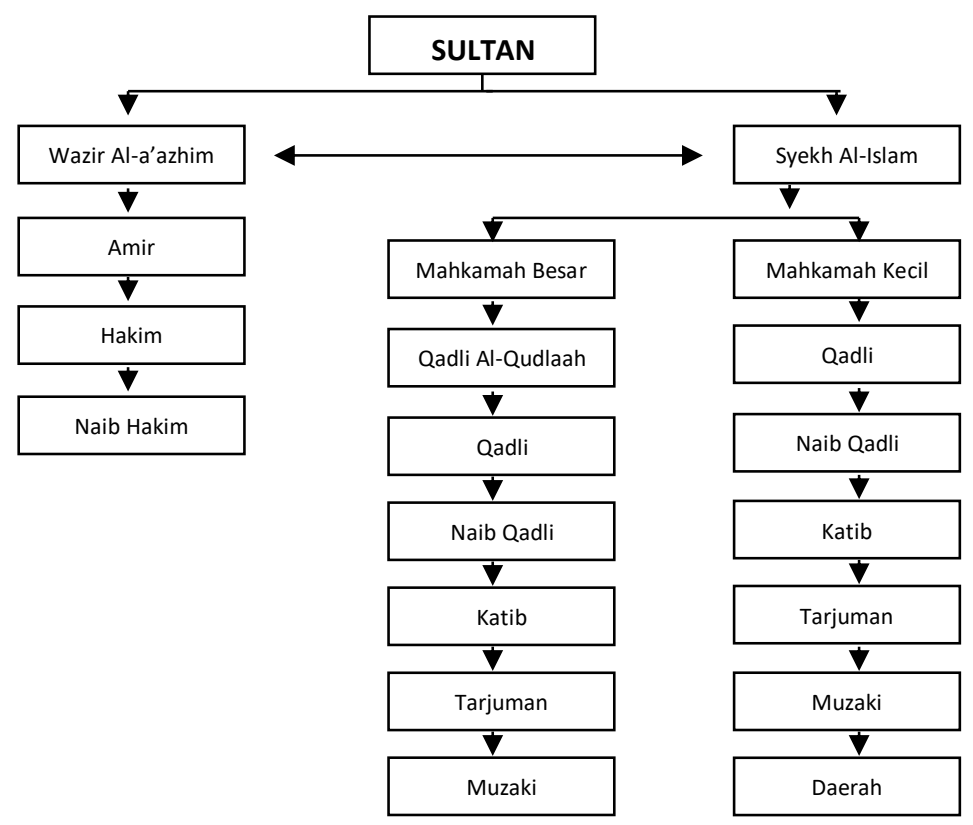

\section{Dasar Penyelenggaraan Peradilan di Kesultanan}

Di Mataram, masa kepemimpinan Sultan Agung, seorang Raja yang alim dan menjunjung tinggi agamanya, pengaruh Islam masuk pada tata hukum yang diwujudkan khusus dalam pengadilan Pradata yang diubah menjadi Pengadilan Surambi, karena diadakan di serambi mesjid Agung. Dasar hukum penyelenggaraan peradilan pada masa kesultanan in adalah adanya pendelegasian wewenang dari Sultan kepada Penghulu. Pada tahun 1645, sultan agung wafat dan digantikan oleh Amangkurat I. Beliau mengubah Pengadilan seperti dahulu kembali. Pengadilan pradata maksudnya perkaraperkara yang diadili oleh Raja dan diadakan di Negaragung, yaitu pusat pemerintahan di Ibukota Negara.

Di Banten, masa kepemimpinan Sultan Hasanudin, pada abad ke-17 di Banten hanya ada satu macam pengadilan, yaitu yang dipimpin oleh Kadhi. Pendelegasian wewenang dari Raja kepada Kadhi.

Di Cirebon, setelah pangeran Girilaya wafat dan meninggalkan tiga anaknya, sehingga Cirebon dibagi tiga, yang dipimpin oleh Sultan Sepuh, Sultan Anom, Panembahan Cirebon. Meski dibagi tiga, namun dalam permasalahan yang besar, mereka tetap bersama. Kemudian dalam menyelesaikan perkara, diserahkan kepada 7 menteri sehingga menjadikan pendelegasian wewenang dari ketiga sultan kepada 7 menteri tersebut untuk menyelesaikan perkara. Adapun ketujuh menteri ini adalah delegasi diantara 
3 orang dari Sultan Sepuh, 2 orang dari Sultan Anom, dan 2 orang dari Panembahan Cirebon. Kemudian pada tahun 1688 terjadi perjanjian de hartogh merupakan dasar hukum sehingga mengubah pengadilan 7 menteri yang diganti menjadi pengadilan 7 jaksa.

\section{Kedudukan Pengadilan}

Di Mataram, kedudukan pengadilan yang menjadi wewenang penghulu, tetap menjadi kekuasaan Sultan Agung, karena ditakutkan bertentangan pada hukum adat yang ada. Meski demikian, penyelesaian yang dilakukan Sultan tidak bertentangan dengan keputusan pengadilan surambi. Dan ini memang keputusan yang dikeluarkan oleh penghulu. Pada tahun 1645, sultan agung wafat dan digantikan oleh Amangkurat I. Beliau mengubah Pengadilan seperti dahulu kembali. Sehingga Pengadilan Pradata tetap ada dalam tangan Raja dan tidak terikat oleh kitab-kitab hukum manapun. Namun setelah ada papakem Cirebon, ada kedudukan lain, yaitu adanya Pengadilan Penghulu yang sebagian besar wewenang pengadilan karta (jaksa) menjadi wewenang Penghulu.

Di Banten, kedudukan pengadilan yaitu dengan dipimpin oleh kadhi. Dalam putusannya, kadhi menetapkan putusan mengadili seseorang, manun kedudukannya tetap ada dibawah raja. Faktanya yaitu karena setiap adanya putusan dari Kadhi harus tetap disahkan oleh Raja.

Di Cirebon, kedudukan 7 menteri ada di bawah tiga Sultan, karena merupaka perwakilan dari ketiga Sultan. Ketujuh menteri ini yang setelah perjanjian de Hartogh itu berubah menjadi tujuh Jaksa, melakukan perbuatan mengadili orang yang berperkara dengan mengeluarkan keputusan yang diambil dari ketujuh jaksa secara bersama-sama yang disebut dengan surat bulat.

\section{Susunan Pengadilan}

Pengadilan surambi ini dipimpin oleh penghulu yang mempunyai beberapa ulama sebagai anggota. Hal ini identik dengan musyawarah. Meski tidak sesuai dengan hukum Islam bahwa figur hakim hanya seorang saja, tetap saja Sultan Agung yang memberi keputusan. Hal ini dilakukan untuk memelihara faham kedaulatan, meski begitu, tetap saja keputusan berdasarkan atau tidak menyimpang dari nasehat putusan Pengadilan Surambi. Pada tahun 1645, sultan agung wafat dan digantikan oleh Amangkurat I. Beliau mengubah Pengadilan seperti dahulu kembali. Perkara-perkara yang diadili berlaku bagi daerah-daerah bekas Negara-negara yang takluk pada mataram, sehingga Negaragung menjadi pusat pengadilan. Susunannya berubah, karena Pengadilan Pradata telah ada dalam tangan Raja dan tidak terikat oleh kitabkitab hukum manapun. Namun setelah ada papakem Cirebon, sehingga terjadi 
pelimpahan kekuasaan dari Pengadilan Jaksa kepada Pengadilan Penghulu. Sehingga Pengadilan Jaksa (karta) hanya mengadili perkara padu saja.

Pengadilan di Banten yang dikepalai oleh Kadhi tidak mempunyai susunan, karena pengadilan dipimpin hanya oleh seorang Kadhi saja. Adapun di Cirebon, susunan pengadilannya yaitu bahwa perwakilan dari ketiga penguasa itu berkedudukan sama. Jadi susunannya yaitu Tujuh Jaksa bersamasama dalam surat bulat, kemudian apabila belum bisa di putuskan maka dilakukan dengan Sidang para Sultan yang setelah Cirebon menerima perjanjian itu, maka residen Belanda pun ikut hadir dalam sidang para sultan.

\section{Kekuasaan Pengadilan}

Pengadilan di Mataram, yaitu pengadilan surambi yang dipimpin oleh penghulu dan dibantu dengan beberapa alim ulama. Pengadilan ini kebiasaan mengadili perkara-perkara mengenai perkara perkawinan dan kewarisan. Kekuasaan penghulu ialah memberikan keputusan-keputusan yang mempunyai arti suatu nasehat (adpis) kepada raja didalam mengambil keputusannya. Pada tahun 1645, sultan agung wafat dan digantikan oleh Amangkurat I. Beliau mengubah Pengadilan seperti dahulu kembali. Perkaraperkara yang diadili berlaku bagi daerah-daerah bekas Negara-negara yang takluk pada mataram, sehingga Negaragung menjadi pusat pengadilan. Sehingga kekuasaan Raja ialah mengadili perkara dalam Pengadilan Pradata dan tidak terikat oleh kitab-kitab hukum manapun. Raja adalah sumber hukum dan sumber keadilan,karena Menurut Amangkurat I, tradisi harus tetap dijalankan, karena wajib untuk memelihara tradisi. Adapun daerah yang telah takluk, diberi wewenang dari Raja kepada wakil Pemerintah Pusat untuk menjalankan pengadilan di daerahnya tapi hanya mengenai perkaraperkara $P a d u$, dan sumbernya yaitu kitab-kitab hukum. Namun setelah ada papakem Cirebon, sehingga terjadi pelimpahan kekuasaan dari Pengadilan Jaksa kepada Pengadilan Penghulu. Sehingga Pengadilan Jaksa (karta) hanya mengadili perkara padu saja.

Adapun di Banten, kekuasaan Kadhi yang merupakan kekuasaan pengadilan tunggal, berkuasa mengadili perkara-perkara (hingga perkara hukuman mati) namun tetap kekuasaannya dibawah raja karena dalam pengesahannya memrlukan pengesahan dari raja.

Selain itu di Cirebon, yang pengadilannya dipimpin oleh tujuh menteri (tujuh jaksa), mempunyai kekuasaan mengadili perkara-perkara yang merupakan hal-hal yang biasa (Tresna, 1978: 25). Adapun kekuasaan mengadili perkara tertentu yang menghasilkan keputusan bersama-sama dengan surat bulat. Adapun apabila salah satu tidak sepakat, maka pengadilan dialihkan kepada sidang para sultan. 


\section{Hukum Substantif}

Hukum materiil yang digunakan di pengadilan mataram ialah kitabkitab fiqh yang bermadzhab syafi' karena Islam masuk pertama kali bermadzhab Syafi'i. Pada tahun 1645, kekuasaan beralih kepada Amangkurat I yang mengubah Pengadilan seperti dahulu kembali. Sehingga kekuasaan Raja ialah mengadili perkara dalam Pengadilan Pradata dan tidak terikat oleh kitab-kitab hukum manapun. Raja adalah sumber hukum dan sumber keadilan, karena menurut Amangkurat I, wajib memelihara tradisi. Adapun daerah yang telah takluk, diberi wewenang dari Raja kepada wakil Pemerintah Pusat untuk menjalankan pengadilan di daerahnya tapi hanya mengenai perkaraperkaraPadu, dan sumbernya yaitu kitab-kitab hukum.

Banten juga memakai hukum materiil yang sama dari Islamnya, adapun tetap terdapat hukum hindu yang merupakan adat dari zaman dahulu. Hukum hindu itu ialah hukuman mati yang dijatuhi oleh Kadhi.

Adapun di Cirebon, kitab hukum yang digunakan yaitu Papakem Cirebon yang didalamnya terdiri dari macam-macam ketentuan dari hukum Jawa-kuno. Diambi dari beberapa kitab, diantaranya Kitab huum Raja Niscaya, undang-undang Mataram, Jaya Lengkara, Kontra Menawa dan Adilulah, juga disebut Surya Alam.

Hukum acara pada kesultanan Mataram belum ada hukum yang mengatur tentang acara pengadilan. Adapaun di Banten pula, seperti itu. Adapun selain kedua kesultanan ini, Kesultanan Cirebon yang di dalam segala perkaranya, yang menjadi acara sidang menteri itu diputuskan menurut "undang-undang jawa".

\section{Penutup}

Sebuah peradilan yang merupakan alat kelengkapan bagi umat Islam dalam melaksanakan Hukum Islam, Peradilan Agama Islam dikhususkan bagi masyarakat yang beragama Islam di Indonesia, sebagai alat kelengkapan pelaksanaan Hukum Islam itu sendiri. Maka Peradilan Agama ini tumbuh dan berkembang di bumi Nusantara yang kemudian disambut dengan senang dan baik oleh masyarakat penduduk Indonesia. Walaupun disadari sepenuhnya bahwa Peradilan Agama khususnya dan Ilmu Pengetahuan Hukum Islam pada umumnya belum pernah berkembang secara menyolok di Indonesia apabila dibandingkan dengan negara-negara yang lainnya terutama sekali yang mayoritas penduduknya beragama Islam, namun demikian konsepsi-konsepsi Hukum Islam telah menyumbangkan suatu potensi pemikiran yang sangat baik bagi perkembangan dan pembinaan Hukum Islam. 
Sejarah Peradilan Islam...... | Ismanto dan Suparman

\section{Daftar Pustaka}

Abdul Halim, Peradilan Agama dalam Politik Hukum Islam, PT. Raja Grafindo Persada, Jakarta, 2000.

Ahmadi Hasan, Adat Badamai Interaksi Hukum Islam dan Hukum Adat pada Masyarakat Banjar, Antasari Press, Banjarmasin, 2009.

Ahmad Rofiq, Hukum Islam di Indonesia, PT Raja Grafindo Persada, Jakarta, 1998.

Cik Hasan Bisri, MS., Peradilan Agama di Indonesia, PT. Raja Grafindo Persada, Jakarta, 2003.

G.P. Rouffaer. Vorstenlanden. Overdruk Uit Adatrechbundel XXXV, serie D, 1931.

Robert Heine Gelderen, Konsepsi Tentang Negara dan Kedudukan Raja di Asia Tenggara (Terjemahan Deliar Noer), CV. Rajawali, Jakarta, 1972.

W.J.S. Poerwodarminta. Baoesastra Djawa. J.B. Wolters, Uitgevers Maatschappij NV, Groningen-Batavia, 1939. 
Sejarah Peradilan Islam....... | Ismanto dan Suparman

$88 \mid \mathrm{H}$ is t o r i a $\mathrm{M}$ a d a $\mathrm{n}$ i 